\title{
DEBATES ABOUT RUSSIA, AMERICA, AND NEW WORLD ORDER: FOUR BOOKS FROM THE 1850s
}

\author{
Ivan I. Kurilla \\ European University at Saint Petersburg, Saint Petersburg, Russian Federation
}

\begin{abstract}
Introduction. The first major crisis of the international relations system founded in Vienna after Napoleonic wars emerged with the series of European revolutions of 1848-1849 and Crimean War of 1853-1856. Not only diplomatic alliances required to be re-evaluated, but also politicians and thinkers challenged the philosophical foundations of the world order. As Russia was the guarantor of the old system, and the United States appeared as an attractive model for the European revolutionaries, the debate on the new world order involved re-assessment of the two countries respective roles and of their future relations. Methods and materials. The article examines books on the subject written during 1850s by four prominent thinkers: American aspiring politician Henry Winter Davis, Russian diplomat Alexei Evstafiev, Polish émigré and American journalist Adam Gurowski and Russian political émigré Ivan Golovin. Analysis. They provided four different visions of the future of the world, and, while never mentioning each other, produced a polyphonic sound of the important debate on the eve of the American Civil War. Results. Bipolarity of the international system predicted by Davis became a fact only a century later, while criticism and praise to American role as a model and an intervening power in European affairs became a constant feature of any subsequent debate.

Key words: Russian-American relations, Adam Gurowski, Henry Winter Davis, Ivan Golovin, Aleksei Evstafiev, European revolutions of 1848-1849, debate on changing the world order.

Citation. Kurilla I.I. Debates About Russia, America, and New World Order: Four Books from the 1850s. Vestnik Volgogradskogo gosudarstvennogo universiteta. Seriya 4. Istoriya. Regionovedenie. Mezhdunarodnye otnosheniya [Science Journal of Volgograd State University. History. Area Studies. International Relations], 2021, vol. 26, no. 5, pp. 225-231. DOI: https://doi.org/10.15688/jvolsu4.2021.5.18
\end{abstract}

УДК $32.001(47+57: 73)^{\text {“ }} 1850 ”$

ББК 66.1(0)5-8
Дата поступления статьи: 08.12.2020

Дата принятия статьи: 27.01.2021

\section{ДЕБАТЫ О РОССИИ, АМЕРИКЕ И НОВОМ МИРОВОМ ПОРЯДКЕ: ЧЕТЫРЕ КНИГИ ИЗ 1850-х ГОДОВ}

\author{
Иван Иванович Курилла \\ Европейский университет в Санкт-Петербурге, г. Санкт-Петербург, Российская Федерация
}

\begin{abstract}
Аннотация. Первым крупным кризисом Венской системы международных отношений стали европейские революции 1848-1849 гг. и Крымская война 1853-1856 годов. Его ход потребовал не только изменения состава дипломатических союзов, но и переосмысления идейных основ мирового порядка. Россия, как гарант старой системы, и Соединенные Штаты Америки, как страна, ставшая привлекательным примером для европейских революционеров, оказались в центре дебатов о новом мировом порядке. Их будущая роль и взаимные отношения потребовали переоценки. В статье рассмотрены книги, написанные в 1850-х гг. четырьмя известными интеллектуалами: начинающим американским политиком Генри Уинтером Дэвисом, русским дипломатом Алексеем Евстафьевым, польским эмигрантом и американским журналистом Адамом Гуровским и русским политическим эмигрантом Иваном Головиным. Они предложили четыре взгляда на будущее мира, и хотя они ни разу не упомянули друг друга, представили полифонию важных дебатов о мировом порядке, состоявшихся накануне американской Гражданской войны. Биполярность международ(?) ных отношений, предсказанная Дэвисом, стала фактом только спустя столетие, а критика и прославление
\end{abstract}


роли Америки как модели и как интервента в европейских делах стали с того момента постоянной частью дебатов о международных отношениях.

Ключевые слова: российско-американские отношения, Адам Гуровский, Генри Уинтер Дэвис, Иван Головин, Алексей Евстафьев, Европейские революции 1848-1849 гг, дебаты о меняющемся мировом порядке.

Цитирование. Курилла И. И. Дебаты о России, Америке и новом мировом порядке: четыре книги из 1850-х годов // Вестник Волгоградского государственного университета. Серия 4, История. Регионоведение. Международные отношения. - 2021. - Т. 26, № 5. - С. 225-231. - (На англ. яз.). - DOI: https://doi.org/10.15688/ jvolsu4.2021.5.18

Introduction. Every international system change meant not only reshuffling of the composition of leading powers or state borders moving; it also included the change of the set of reference, the language describing the main principles of the system. Search for a new explanatory model followed debates in each country but also between diplomats and intellectuals of different nations. In our own times, when the world once again faces the need of a new international relations language, it seems justified to turn to the study of the debates during the first crisis of the European concert, or the Vienna system in the middle of the $19^{\text {th }}$ Century. Many arguments and philosophies emerged there were rejected by the decision-makers of that epoch, but some of them would be returned and used decades later. This article will address the debate that took place on the pages of four books written by American and Russians of different origin and occupations in the $1850 \mathrm{~s}$.

European Revolutions of 1848-49 and Crimean War of 1853-56 exposed the crisis of the Vienna system based on the legitimist philosophy and Holy Alliance as its guarantor. Radical thinkers inspired by revolutionary wave offered new ideas to replace those fundamentals. The respective international roles of Russian Empire as a protector of legitimist monarchies and of the United States of America whose political system suddenly turned to be a model and template for the European revolutionaries, fell into the center of this rethinking.

As a result of that intellectual work new ways to comprehend international politics emerged. Thus, in the United States politicians united in the "Young America" group attacked the legitimist system in Europe, offering instead democratic sovereignty and nations' rights. That philosophy led to the discursive assault on the Holy Alliance and Russian Empire as an institute and the country cementing the old order. US press published articles criticizing Russia for its role in suppressing Magyar rebellion of 1849; soon the first book on the US - Russian relations appeared in print, its author Henry Winter Davies described two countries as natural antagonists. Such a position did not stay unanswered. Russian consul in New York City Alexei Evstafiev, Polish émigré Pan-Slavist Adam Gurowski and Russian émigré Ivan Golovin each wrote a book on Russia or the United States suggesting alternative views on the future of two countries and their relations.

Russian diplomat attacked American democracy as a principle and US export of democracy to Europe. Polish intellectual, following Mikhail Bakunin's ideas, suggested Nicholas I in 1848 to get rid of the Holy Alliance and get support from the Slavic people thus shaping first Pan-Slavic dreams [3, p. 147]. Russian émigré also criticized American political system for its flaws and predicted imminent breakup of the Union but hoped it will clean itself from the worst problems and emerge as a new model for Europe.

So, from different sides and with variant directions American and Russian intellectuals attempted to fill the vacuum of ideas in the sphere of international relations, find place in the system for both countries and predict the character of the relations between them in the new era.

Methods. Russian-American relations in the middle of the $19^{\text {th }}$ Century were subject of the monographs published by US historian Norman E. Saul [21], and Russian scholars Nikolai N. Bolkhovitinov $[1 ; 2]$ and Valerii N. Ponomarev $[2 ; 8]$. The author of this article has also published a book on that period. However, no scholar has focused his or her research on the essence of the debates about Russia and America that happened in the 1850s. Four authors of the books written during that decade got unequal share of interest from historians. Thus, Aleksei Evstafiev's career was researched by Leo Wiener [27], Valeri 
Ponomarev [9], Susan Smith-Peter [23], and in my own articles [5; 19]. Adam Gurowski was a subject of many publications in Poland, and a booklength English-language biography by LeRoy Fischer [14] plus informative article in Russian by Henryk Głębocki [3]. Ivan Golovin attracted less attention, even though Alexander Herzen devoted to him special chapter in his famous book [7]. The most interesting analysis of an American chapter of Golovin's life was provided by Max M. Laserson in his classic book [20, pp. 155-161]. Other publications include rather superficial article by T.M. Koloskov [4] (who later defended a dissertation about Golovin) and articles by V. Slivovskaya [10; 22]. Finally, Henry Winter Davis's activity in Congress on the eve and during Civil War were researched in many texts on the origins of Radical Reconstruction; his earlier biography was studied by Bernard C. Steiner [24] and Gerald S. Henig [17]. Nevertheless, their books that I aim to compare in this article got merely tangential attention in the previous scholarship and were never considered within the same context of changing set of references in international relations. My approach to the study is based on constructivist methods of historical inquiry, with its focus on perceptions and identity-building as represented in the texts written with the authors' hopes to influence international relations.

Analysis. In the first half of the $19^{\text {th }}$ century, Americans frequently compared the U.S. political system, way of life or culture to the English or French models. When they needed an example of a society that was the absolute opposite of their own, they used the Russian Empire. In the spring of 1848 , as the Senate discussed the territorial acquisitions that had resulted from the Mexican War, Senator Daniel Webster cited Russia as a country whose example the United States could not emulate: "Russia may rule in the Ukraine and the provinces of the Caucasus and Kamtschatka by different codes, ordinances, or ukases. We can do no such thing". In other words, the United States could not extend its Constitution to the alien population of the new territories [25, p. 568]. For the democratic United States, the Russian Empire was a political model opposed to its own, one that was gradually becoming a significant Other for American democratic identity.

The early aftermath of the European revolutions of 1848-1849 provided the first opportunity for Americans to amend their selfidentification to reflect the new importance of their republican model for the Old World. This seemed to call for radical change to Russia's image in American political debates and journalists' depictions, especially those of journalists agitated by exiled Hungarian leader Kossuth's tour in the United States in 1851-1852. Thus, several magazines of the era published negative reviews of an American journalist George L. Ditson's book about his Caucasian travels. The reviewers accused the author of being biased toward Russia and therefore failing to recognize that, as the New Englander and Yale Review put it, the Circassians were "fighting for their lives and their freedom". In a revealing manner, the reviewer used American analogues to explain Russian realities: "By the treaty of Adrianople in 1829 Turkey ceded to Russia all the littoral of the Black Sea; which is very much as if Mexico should cede to the United States Cuba or Porto Rico" [11, pp. 107-108]. Whereas Ditson in his book compared the Circassians to American Indians, calling the Russian advance in the Caucasus a "civilizing" move, an author writing in the US Democratic Review doubted the Russian civilizing mission and compared the people of the Caucasus to "the followers of Leonidas at Thermopylae" [12, pp. 301-304]. Thus, the very same events were judged in opposite ways in American publications simply because different analogies were used.

Many democratic and nationalist European revolutionaries considered the US the model for their constitutional projects. Thus, the new generation of American politicians dreamed of revolutionizing the international order to position the model democratic republic as the leading state rather than a mere survivor within the existing world system based on legitimism and monarchical rule. As Russia was the main guarantor of the Vienna system of international relations, created after the Napoleonic wars, it could not escape becoming a major target. The polarization of views on the philosophy of international relations in the 1850 s is well demonstrated by several books written and published in the United States that aimed to challenge Alexis de Tocqueville's prophecy that Russia and the United States were destined to master half the world each.

In 1854, George N. Sanders, the former editor of the US Democratic Review and one of 
the Young America leaders, who was now the U.S. consul in London, invited exiled revolutionaries to dine at his house. Russia was represented by Alexander Herzen, who perspicaciously linked the "idea of giving a diplomatic dinner to the enemies of all existing governments" to the Americans' belief that they sent ambassadors "not to kings but to peoples" [18, p. 478].

The most comprehensive framework that would have revolutionized the international system in that period came in a book published by a young Whig politician, Henry Winter Davis, in 1852. Titled The War of Ormuzd and Ahriman in the Nineteenth Century, it became, in a historical irony, the first book devoted to U.S.-Russian relations and one of the first American books on international relations. The structure of the book explained the author's idea: from the history of the Holy Alliance created in Vienna, he proceeded to the sequence of "revolts against the Holy conspirators" in 1830 and 1848-1849, then continued by contrasting "American and English liberty" with "Russian Dictatorship". The last chapter was devoted to "The American Republic and the Last War of Freedom and Despotism" that would eventually erupt [13]. Davis later would become a Congressman from the Know Nothinginfluenced American Party and a Radical Republican during the Civil War.

This short but sharp surge in anti-Russian sentiment among Americans, and the general tendency to replace fundamentals of international relations with new doctrines forced the senior Russian Consul General in New York, Alexei Evstafiev (who had proved himself an efficient propagandist 40 years earlier, during the War of 1812), to write a monograph criticizing the U.S. political system and the country's foreign policy. Evstafiev completed his book The Great Republic Tested by the Touch of Truth in May 1852: although it was never published and thus did not influence the public in either country, it skillfully summarized the Russian view of American democracy.

Evstafiev presented a comparison between "one of the extremes, the popular American Republic" and "its antipodal Russian Despotism". The Russian diplomat considered the main question of his time: "Whether monarchies combine against republics, or republics are sworn to destroy all monarchies". Russian diplomat asked whether American democracy was "a heavenly nurse and protectress of the rights and happiness of man" or "a bright ignis fatuus, enticing millions to perdition, ... a willful bigot sparing none opposing to her, ... and sowing where she can the Dragon-teeth of Revolution" [28, pp. 5-6]. He pounced on the United States and on Americans, criticizing the attitude that would later become known as American exceptionalism, and was especially indignant about the American belief "that nothing anti-republican has any value, that no good, physical or moral, can spring from the soil of monarchy", reminding Americans of the irony of "their own doctrine that, in all respect, a negro slave is better off, much better, than the negro in a state of freedom!!" [28, pp. 5-7]. Evstafiev paid special attention to the menace of American spread of democracy in Europe, thus not only reacting to the new doctrine of popular sovereignty but anticipating Russian fears from future centuries: "It is quite clear, that, if it depends on their will, no choice but to join in the worship of their Jaggernauth, or to be crushed beneath its ponderous wheels, will be left to the nations of the Earth!" [28, p. 10].

At the time when Russian diplomat put in question the democratic proselytism of Americans, Mikhail Bakunin addressed Emperor Nicholas from Peter and Pavel fortress jail urging him to abandon Holy Alliance principles. Polish йmigrŭ from Russia Adam Gurowski also propagated this change of Imperial foreign policy. In 1848, he suggested to turn from Holy Alliance to Slavic nations of Europe as Russian main allies thus shaping early Pan-Slavic ideas [3, p. 147].

After disappointment in Russian tsar's ability to lead Slavic race, Gurowski moved to the United States and further developed his views on the Russia's role. They still provided new vision of the future of international relations in Europe. In his book Russia As It Is, published at the beginning of Crimean War (1854), Adam Gurowski challenged Tocqueville's comparison of the two countries, arguing that there were no similarities between Russia and America beyond their collective geographic vastness. Instead, Gurowski insisted that "Russia is saddled by despotism [while] America initiates history and humanity into a new era - which a century ago was looked on as an Utopia constructing a social order on the foundations of equality and liberty" [16, pp. 261-262]. 
We should pay some attention to Count Gurowski and his ideas to understand his role in the debates. In his young years, Polish intellectual was close to Franzois Marie Charles Fourier, a French socialist. After participating in the Polish rebellion, Gurowski got disappointed in the Polish national movement and promoted panslavist ideas with Russian Empire uniting all Slavic peoples. In the 1840s he, however, emigrated again, while keeping his faith in the global role of the Russian people instead of Russian tsar. At that point Gurowski developed his understanding of a Russian peasant community as a nucleus of democracy and socialism, thus making Russian future much closer to the American visions.

Gurowski's articles and book on Russia offered American readers very different view of the future Russian-American relations. He aimed at the central point of the recent debates: "For some time Russia has more and more attracted general attention. This mighty colossus, overtopping Europe and Asia, is for many but a dark cavern filled with demoniac forces, which, let loose, are to extinguish light, engulf civilization, and stop the onward progress of the European world, spreading over it all the plagues and curses of darkness... I shall try to give an insight into the heart, the life and the muscles of this political giant" [16, p. iii].

The main hope for the better future, the hope that should alter an image of menacing Empire was Russian people. According to Gurowski, "beyond the Autocracy there exists in Russia a people with a destiny reaching beyond the temporary darkness enveloping it, which is caused by successive exigencies rather than by everlasting historical laws. Not the ruling power or the existing government, not the superior strata of society, contain the promise of the future. The people alone is its bearer; the people, the present lower classes, however behind-hand and uncivilized they may now appear" [16, p. viii].

Gurowski ended preface to his book with an attempt to combine American vision of the future democracy, socialist hopes of the just society and his own ideas of Pan-Slavic brotherhood: "The social organization, the institutions of America, raise her into the higher regions of humanity. How long will it be before Europe follows in the wake of her younger sister? Europe must still traverse many crises ere she shall free herself from the mental and political fetters forged by centuries as long as the past of the whole race. In this struggle the special group of the Slavic family must necessarily act its part. The present book aims to show how in the future, the Slavi may harmonize with the eternal laws of nature and the general destinies of mankind. All the European races and nations, which for centuries stood prominent in history, in bloody struggles, have tried their hands to establish social freedom and harmony. Hitherto their efforts have been unsuccessful. It may be, that the Slavi, who come the last, who have suffered and suffer the most, will give a more propitious lift to this great work, - which heretofore, as regards Europe, has been like the task of Tantalus" [16, p. xiv]. Adam Gurowski became an influential figure in American antebellum debates; his image of the Russian peasant community as a nucleus of a future "town-meeting system, like that of New England" captured such prominent American reformer as Theodore Parker [26, pp. 80-81].

Another émigré, revolutionary activist Ivan Golovin, took somehow opposite approach, making an attack on America in his Stars and Stripes (1856). He denounced European "panegyrists of American democracy" and insisted "that unlimited competition, unbounded love of material interests, are not fit to resolve the questions pending in our age". Praising America as an open field for social experiments (and describing the socialist commune Icaria and even Mormons as a kind of socialist community), Golovin caustically addressed the political principles upon which the United States was built: "democracy is developing the material instincts of man at the expense of his intellect and morality; $<\ldots>$ and that honour and intellect being in minority with man, the government of the majority is that of dishonesty and stupidity" [15, pp. 7, 113].

Even more interesting is Golovin's direct mention of the new role the United States was vested by the European revolutionaries, that of the leader of a new democratic world order: "For goodness sake, no intervention at such a distance, unless unavoidably compelled, - exclaimed Golovin. - They find in Europe much difficulty in keeping up revolutions made by patriots, how could they save those made by foreigners, or helped by them? They have already crushed too many republics, let us save at least that one of 
the New World. Old Europe makes me despair of her fate, let us save at least the stars and stripes - 'Who would be free, themselves must strike the blow"' [15, p. 223]. Golovin turned also to an American side of the "democracy promotion" criticizing Americans for their ignorance: "Foreign chancellors ought not to expect better proceedings than the Yankees are in the habit of resorting to. However, the stronger is the prediction to propagate the American principles in Europe. The best government is that which lays in the interest of the greatest number granted, but if the majority will destroy every good, beautiful, or great things - shall the minority submit? Thus I will return to Europe, Arkansas or Alabama having, for me, not the interest of MoldWallachia or Greece" [15, p. 224].

Golovin here seemed to follow Evstafiev's criticism of the United States; however, he did not attack American democracy. Contrary to that, Golovin insisted that there was no real democracy in America: "The United States are pursuing a wrong way in their politics and murals, falsely interpreting their destination, and losing sight of the principles which presided at their formation. While European thinkers, led into error by the panegyrists of American democracy, consider the institutions of the United States as a perfect model, deeper philosophers, already judging of the tree after its fruit, think that unlimited competition, unbounded love of material interests, are not fit to resolve the questions pending in our age" $[15$, p. vii]. Golovin, however, used America as a "dark double" of Russia when he wrote a book about "Russian Uncle Tome", applying Harriett Beecher-Stowe's social criticism to Russian serfdom [6, p. 39].

Results. Four books published during the crisis of European concert in the mid-19 $19^{\text {th }}$ century provided different recipes for amending international relations. Davis suggested introduction of a bipolar vision shaped by dichotomy between autocracy and democracy, represented by Russia and the United States. Evstafiev defended existing order blaming American republic for spreading "dragon teeth of revolutions". Gurowski hoped that Russia will lead Slavic nations and peasant communes become nucleus of democracy thus making mighty Slavic union an improved edition of the United States. Golovin also criticized American republic for corruption of its own principles but expressed concerns that more active participation in the European affairs would harm the United States and may even lead to the collapse of the young republic.

In the mid-1850s, increased domestic tensions combined with the collapse of the postNapoleonic world order hurt the Russian Empire, the United States, and European stability and started a process of reevaluating fundamentals of the international relations. The writing and publication of books in the field that we would now call comparative politics was a new phenomenon. It reflected the fact that both American and Russian society perceived approaching crises; the books' content also foreshadowed the bipolar vision of the world.

\section{REFERENCES}

1. Bolkhovitinov N.N. Russko-amerikanskie otnosheniia i prodazha Aliaski: 1834-1867 [Russian-American Relations and the Sale of Alaska, 1834-1867]. Moscow, Nauka Publ., 1990. 368 p.

2. Bolkhovitinov N.N., Ponomarev V.N. Amerikanskie vrachi v Krymskoi voine [American Surgeons in the Crimean War]. SShA-Ekonomika. Politika. Ideologiia, 1980, no. 6 (June), pp. 63-69.

3. Glembotskii Khenrik. GrafAdam Gurovskii (1805-1866) i missiia Rossiiskoi imperii: Metamorfozy politicheskogo radikalizma [Count Adam Gurowski (1805-1866) and the Mission of Russian Empire: Metamorphoses of Political Radicalism]. Ab Imperio, 2009, no. 2, pp. 131-154.

4. Koloskov T.M. I.G. Golovin - borets protiv samoderzhaviia i krepostnichestva [I.G. Golovin Fighter Against Autocracy and Serfdom]. Vestnik Moskovskogo universiteta. Seriia 8. Ekonomika, filosofiia, 1963, no. 6, pp. 97-100.

5. Kurilla I. «Velikaia respublika, proveriaemaia prikosnoveniem istiny»: Aleksei Evstafev i pervyi opyt rossiiskoi kontrpropagandy v SShA ["The Great Republic Tested by the Touch of Truth": Aleksei Evstafiev and the First Russian Counter-Propaganda Effort in the USA]. Kurilla I.I., ed. Americana. Vyp. 14. Strany Severnoi Ameriki i voina. Volgograd, Izdatelstvo Volgogradskogo gosudarstvennogo universiteta, 2014, pp.313-325.

6. Lemke M.K. Emigrant Ivan Golovin (Po neizdannym materialam) [Emigrant Ivan Golovin (Based on Unpublished Materials)]. Byloe, 1907, no. 5/17, pp. 24-53.

7. Neizdannaia glava iz«Bylogoi dum»A.I. Gertsena [Unpublished Chapter from "My Past and Thoughts" by A.I. Herzen]. Byloe, 1907, no. 5/17, pp. 1-23. 
8. Ponomarev V.N. Krymskaia voina i russkoamerikanskie otnosheniia [Crimean War and RussianAmerican Relations]. Moscow, Institut Rossiiskoi istorii RAN, 1993. $232 \mathrm{p}$.

9. Ponomarev V.N. Polveka za okeanom: rossiiskii diplomat i literator Aleksei Evstafev [Half a Century Overseas: Russian Diplomat and Literary Man Aleksei Evstafiev]. Amerikanskii ezhegodnik, 1990. Moscow, Nauka, 1991, pp. 191-205.

10. Slivovskaia V. Ivan Golovin v emigratsii i ego polskie sviazi (40-50-e gody XIX v.). [Ivan Golovin in Emigration and His Polish Connections (40-50s of the $19^{\text {th }}$ Century)]. Issledovaniia po istorii polskogo obshchestvennogo dvizheniia. XIX-nachala XXv. Moscow, Nauka Publ., 1971, pp. 265-290.

11. Caucasus. New Englander and Yale Review. 1851 (February), vol. 9, no. 33, pp. 88-109.

12. Circassia and the Caucasus. United States Magazine and Democratic Review, 1852 (October), vol. 31, no. 172, pp. 301-304.

13. Davis H.W. The War of Ormuzd and Ahriman in the Nineteenth Century. Baltimore, James S. Waters, 1852 , VIII. $450 \mathrm{p}$.

14. Fischer LeRoy H. Lincoln's gadfly, Adam Gurowski. Norman, University of Oklahoma Press, 1964. $301 \mathrm{p}$.

15. Golovin I. Stars and Stripes, or American Impressions. London, New York, 1856, VIII. 312 p.

16. Gurowski A. Russia As It Is. New York, 1854, XVI. 312 p.

17. Henig G.S. Henry Winter Davis: Antebellum and Civil War Congressman From Maryland. Boston, Twayne, 1973. $332 \mathrm{p}$.
18. Herzen A. My Past and Thoughts. Berkeley, University of California Press, 1982. 684 p.

19. Kurilla I. "Russian Celebrations" and American Debates About Russia in 1813. Nationalities Papers: The Journal of Nationalism and Ethnicity, 2016, vol. 44, no. 1, pp. 114-123.

20. Laserson Max M. The American Impact on Russia: Diplomatic and Ideological. 1784-1917. New York, The Macmillan Co., 1950. 441 p.

21. Saul N.E. Distant Friends: The United States and Russia, 1763-1867. Lawrence (Kan.), University Press of Kansas, 1991. 448 p.

22. Sliwowska W. Un Émigré Russe En France: Ivan Golovine. 1816-1890. Cahiers du Monde Russe, 1970, no. 11-2, pp. 221-243.

23. Smith-Peter S. The Russian Federalist Papers: Aleksei Evstaf'ev, the War of 1812, and RussianAmerican Relations. Whisenhunt W.B., Saul N.E., eds. New Perspectives on Russian-American Relations. New York, Routledge, 2016, pp. 20-35.

24. Steiner B.C. Life of Henry Winter Davis. Baltimore, John Murphy, 1916.416 p.

25. Webster D. Objects of the Mexican War. The Great Speeches and Orations of Daniel Webster. Boston, Little, Brown and Company, 1889. 707 p.

26. White A.D. Autobiography of Andrew Dickson White. New York, The CenturyCo, 1922, vol. 1, XXII. 601 p.

27. Wiener L. The First Russian Consul at Boston. Russian Review, 1916, April, vol. 1, no 3, pp. 131-140.

28. Yevstafiev A.G. The Great Republic Tested by the Touch of Truth (Manuscript). New York Public Library. Manuscripts and Archives Division. Aleksyei Grigoryevich Yevstafiev Papers, 1814-1852.

\section{Information About the Author}

Ivan I. Kurilla, Doctor of Sciences (History), Professor, Faculty of Political Science, European University at Saint Petersburg, Gagarinskaya St, 6/1 A, 191187 Saint Petersburg, Russian Federation, ikurilla@eu.spb.ru, https://orcid.org/0000-0001-7144-2007

\section{Информация об авторе}

Иван Иванович Курилла, доктор исторических наук, профессор факультета политических наук, Европейский университет в Санкт-Петербурге, ул. Гагаринская, 6/1 лит. А, 191187 г. СанктПетербург, Российская Федерация, ikurilla@eu.spb.ru, https:/orcid.org/0000-0001-7144-2007 